\title{
EVALUASI KEBIJAKAN PERDA KOTA PALU NO. 3 TAHUN 2018 (Studi Kasus Penanganan Gelandangan/Pengemis Anak dan Perempuan di Kota Palu)
}

\author{
Muthia
}

\begin{abstract}
The rapid urban development is the goal of many regions in Indonesia. However, urban development often creates new problems, including homeless and children/women beggars. A number of tactical steps have been carried out by the government in reducing the number of homeless and child/women beggars in Indonesia. One of them is through a normative approach, which is regional regulations, as applied in Palu, Central Sulawesi by issuing Regional Regulation No. 3 of 2018 on the management of homeless people and children/women beggars. However, these efforts have not yet reduced the number of homeless and beggars for children/women. This article aims to identify the effectiveness of Palu Regulation No. 3 of 2018 in dealing with the problem of homeless people and children/women beggars. By applying the implementation-style analysis of Grindle to evaluate Regional Regulation (Perda) No.3 of 2018, this research applied a comparative literature study data collection method from secondary data that the researchers had collected, including periodic reports from the Palu City Government and related agencies. In addition, data were also obtained from the results of field observation. Some points that were observed in this study were in front of the office of Regional People's Representative Assembly (DPRD) of Palu. The results showed that he implementation of Palu Regional Regulation No. 3 of 2018 as seen from the policy content had been optimized.
\end{abstract}

\section{Keywords: Policy Implementation, Grindle, Homeless, Beggar, Regional Regulation}

\section{PENDAHULUAN}

Kemiskinan masih menjadi satu persoalan yang sangat serius di Indonesia. ${ }^{1}$ Dengan tingkat kemiskinan yang terbilang sangat tinggi, mencapai 9,78 juta jiwa penduduk. Angka ini bahkan bisa lebih besar jika melihat situasi di lapangan. Pendeknya,

\footnotetext{
${ }^{1}$ Masyuri Imron, Kemiskinan Dalam Masyarakat Nelayan, Jurnal Masyarakat dan Budaya, Vol. 5, No. 1 (2003), 63-82.
} 
kemiskinan sejauh ini di Indonesia masih tergolong masalah yang paling mendesak untuk segera di selesaikan. Berbagai upaya telah di lakukan oleh pemerintah, namun hasilnya belum terlihat cukup signifikan. Seperti misalnya di tingkat pemerintah daerah, berbagai perda dan aturan gubernur, bupati walikota telah di terbitkan. Tujuannya, agar angka kemiskinan mampu di tekan. Namun hasilnya sejauh ini belum terlihat banyak. Sebagaimana data yang telah di rilis oleh BPS, angka kemiskinan masih menyentuh di angka 9 jutaan.

\section{Grafik 1}

Jumlah dan Persentase Penduduk Miskin, 2006-Maret 2020

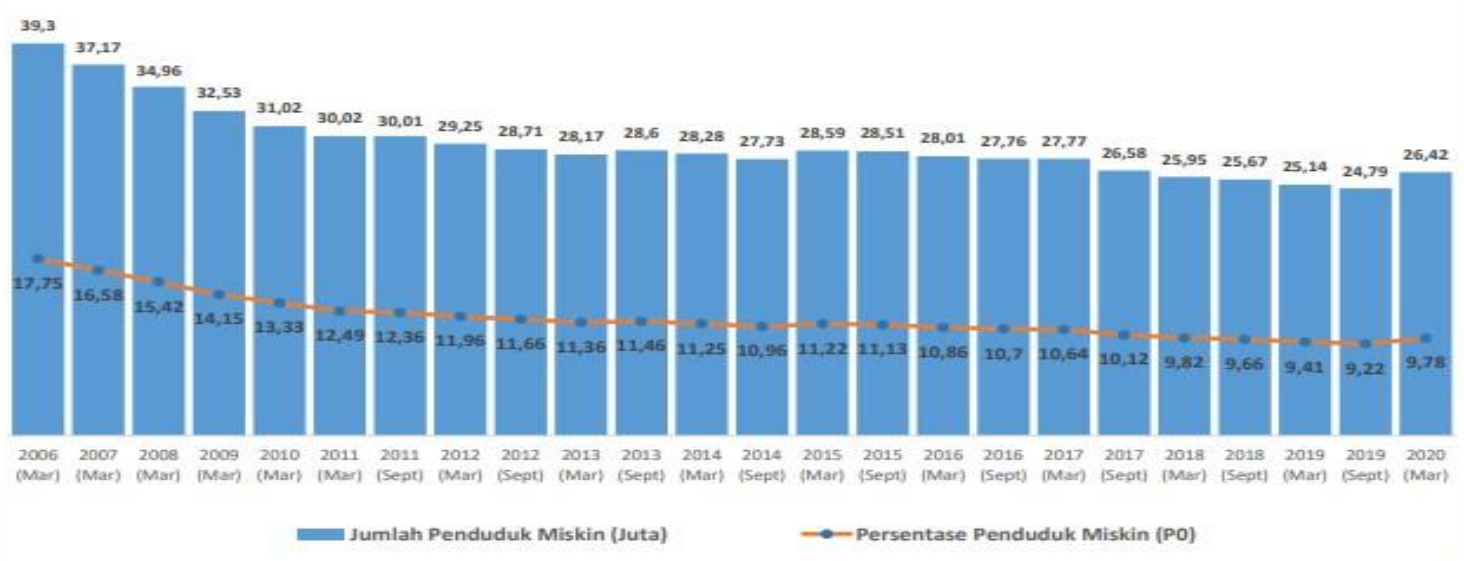

Sumber: BPS, 2020.

Terkhusus di Sulawesi Tengah, berdasarkan data BPS bahwa Jumlah penduduk miskin di Sulawesi Tengah (Sulteng) pada bulan September 2020, mencapai 403,74 ribu orang atau 13,06 persen, bertambah sebesar 5 ribu orang dibandingkan dengan kondisi Maret 2020 yang sebesar 398,73 ribu orang atau 12,92 persen. Data jumlah penduduk miskin kabupaten/kota di Sulteng pada Maret 2020, Parigi Moutong menempati urutan teratas. Total penduduk miskin di daerah ini sebanyak 78.760 jiwa. Kabupaten Donggala menempati urutan ke dua dengan total penduduk miskin sebanyak 53.170 jiwa, disusul Kabupaten Poso sebanyak 40.200 jiwa, serta Kabupaten Tolitoli sebanyak 30.510 jiwa. Selanjutnya, Kabupaten Sigi 
sebanyak 30.000 jiwa, Kabupaten Banggai 28.160 jiwa, Kota Palu 26.890 jiwa, serta Tojo Una-una 25.430 jiwa. Kemudian, Kabupaten Buol sebanyak 22.930 jiwa, Morowali Utara 18.380 jiwa, Banggai Kepulauan 16.700 jiwa, Morowali 16.500 jiwa, dan Banggai Laut 11.090 jiwa. Tingginya angka kemiskinan berdampak domino pada banyak aspek. Salah satu diantaranya, kemiskinan memicu tingginya gelandangan dan anak jalanan. ${ }^{2}$

Akibat kemiskinan, banyak orang yang kemudian karena kesulitan mendapat pekerjaan terlempar dari arena yang begitu keras, menjadi gelandangan. Tidak sedikit juga diantara mereka yang menjadi gelandangan masih berada pada kisaran usia yang sangat muda, yaitu berada pada usia anak. Kemiskinan, gelandangan dan anak jalanan satu paket persoalan sosial yang hingga saat ini belum mampu di tuntaskan oleh pemerintah. Keduanya saling terkait sangat erat. Kemiskinan memicu munculnya gelandangan dan anak jalanan. Di Indonesia sendiri, gelandangan dan anak jalanan telah lama menjadi perhatian pemerintah. ${ }^{3}$ Terutama dalam 3 tahun terakhir ini, pemerintah terus berupaya untuk menekan angka gelandangan dan anak jalanan khususnya yang bermukim di kota-kota besar. Meskipun belum menunjukan hasil yang cukup signifikan, setidaknya di tiga tahun teakhir angka gelandangan dan anak jalanan di Indonesia sudah mampu di tekan ke angka 16.000 di tahun 2018.

Tabel. 1 Pengemis Gelandangan dan Anak Jalanan di Indonesia

\begin{tabular}{|c|l|c|}
\hline No & Tahun & Data Gelandangan dan Anak Jalanan \\
\hline 1 & 2016 & 23.100 \\
\hline 2 & 2017 & 23.600 \\
\hline 3 & 2018 & 16.000 \\
\hline
\end{tabular}

Sumber: Diolah dari Berbagai Sumber Sekunder, 2021

\footnotetext{
${ }^{2}$ Moh Anif Arifani, Avid Leonardo Sari, and Rifkah Rifkah, Aplikasi Regulasi Pembinaan Anak Jalanan Oleh Dinas Sosial Dan Penanggulangan Kemiskinan Kota Bandung, Jurnal Ilmu Sosial dan Ilmu Politik, Vol. 8, No. 2 (2018).

${ }^{3}$ Ade Putri Febriandini and others, Studi Implementasi Program Kesehatan Ibu Dan Anak Di Puskesmas Tlogosari Kulon Kota Semarang, Journal Of Public Policy And Management Review, Vol. 5, No. 2 (2016), 1-14.
} 
Sejumlah studi yang ada di Indonesia sejauh ini memang belum banyak melihat gelandangan dan anak jalanan dalam kacamata evaluasi kebijakan. ${ }^{4}$ Kebanyak studi-studi mengenai gelandangan dan anak jalanan masih lebih banyak di lihat dari persoalan sumber daya, soft skill dan aspek budaya yang minim atau jika tidak di potret dengan pendekatan preventif melalui pemberian pelatihan. Studi seperti ini penting, terutama untuk melihat bakat dan potensi pada gelandangan dan anak jalan tetapi terbatas karena tidak mampu memberikan penjelasan yang utuh tentang efektfitas perda. Padahal sejauh ini, strategi pemberantasan gelandangan dan anak jalanan banyak di dekati dengan pendekatan normatif berupa perda dan aturan lainnya yang di keluarkan oleh pemerintah di daerah. Sehingga artikel ini penting untuk memberikan gambaran tentang persoalan gelandangan dan anak jalanan yang terjadi di Indonesia secara umum, di kota palu pada khususnya.

\section{METODE PENELITIAN}

Penelitian ini menggunakan metode kualitatif deskriptif. Dengan model pengumpulan data di lakukan melalui observasi lapangan. Lokasi observasi yang dilakukan adalah kota Palu, Sulawesi Tengah dengan titik observasi di depan kantor DPRD kota Palu. Lokasi ini di pilih karena area ini menjadi representasi dari instansi pemerintah kota Palu, yang sekaligus sebagai kantor dari lembaga legislasi di daerah, yang punya kewenangan merumuskan dan mengevalusia sebuah perda. Selain itu, titik ini di pilih pasalnya hampir setiap hari terutama menjelang sore banyak gelandangan yang memilih lokasi ini untuk sekedar istrahat. Selain observasi langsung, pengumpulan data juga di lakukan dengan mengupulkan dokumendokumen skunder. Beberapa dokuemn skunder berasal dari laporan berkala yang

\footnotetext{
${ }^{4}$ Arsidik Asuru Abdul Syaban, La Iru, Implementasi Kebijakan Pemerintah Daerah Di Bidang Pendidikan Non Formal Pada Anak Jalanan Di Kota Kendari, Journal Of Chemical Information And Modeling, 53.9 (2013).
} 
telah dirilis oleh pemerintah kota Palu, diantaranya laporan berkala dari Badan Pusat Statistik kota Palu, serta dokumen- dokumen lainnya yang relevan dengan penelitian yang di lakukan. Sumber data terakhir, berasal dari media online berupa pemberitaan yang telah dirilis oleh beberapa media yang kredibel seperti kompas.com, tempo.com dan radar sulteng.

Penelitian menggunakan kacamata analisis implementasi Grindle. Pendekatan ini di pilih sebab, implementasi Grindle menitikberatkan implementasi kebijakan pada aspek evaluasi, selaras dengan tujuan penelitian yang akan dilakukan yaitu ingin melihat efektifitas berlakunya perda dalam hal ini aspek evaluasi pelaksanaan perda. Dengan melihat prinsip dasar dari implementasi Grindle, pendekatan ini dianggap paling relevan dalam melihat proses evaluasi Perda Kota Palu No. 3 Tahun 2018 tentang Gelandangan/Pengemis Anak dan Perempuan di Kota Palu.

\section{PEMBAHASAN}

\section{Konsep Implementasi Perda Grindle}

Kajian Implementasi kebijakan menjadi salah satu tema kajian yang sangat menarik. Dalam perkembangannya, kajian implementasi kebijakan mulai banyak di minati di kalangan akademisi. ${ }^{5}$ Sebuah pemandangan yang baru, mengingat selama ini tema mengenai implementasi kebijakan hanya banyak di bicarakan di kantorkantor instansi pemerintahan. Implementasi kebijakan sangat identitk dengan birokrat pemerintahan. Seiring dengan perkembangan yang berlangsung, implementasi kebijakan mulai mendapat ruang di dunia akademik. Implementasi kebijakan di bicarakan dan di perdebatkan di ruang-ruang seminar. Sejumlah Perda menjadi sorotan dalam kajian implementasi kebijakan. Salah satu pendekatan yang banyak

\footnotetext{
${ }^{5}$ Kardin Simanjuntak, Implementasi Kebijakan Desentralisasi Pemerintahan di Indonesia, Jurnal Bina Praja, Vol. 07, No. 02 (2015), https://doi.org/10.21787/jbp.07.2015.111-130;
} 
digunakan baik oleh praktisi maupun akademisi dalam melihat evaluasi dan implementasi kebijakan adalah pendekatan Grindle. ${ }^{6}$

Menurut pendekatan Grindle implementasi kebijakan bertumpu pada dua aspek utama, yaitu aspek isi kebijakan dan lingkungan kebijakan. Isi kebijakan terdiri dari Kepentingan Kelompok Sasaran, Tipe Manfaat, Derajat Perubahan yang diinginkan, letak pengambilan keputusan, Pelaksana Program dan Sumberdaya yang dilibatkan. Sementara itu, untuk aspek lingkungan kebijakan terdiri dari kekuasaan, kepentingan dan strategi aktor yang terlibat, karakteristik lembaga dan kekuasaan, serta kepatuhan dan daya tanggap. Pendekatan ini melihat, jika keberhasilan sebuah kebijakan bisa di lihat dari dua aspek ini, isi kebijakan dan lingkungan kebijakan. Pandangan ini sekaligus memberikan atensi yang spesial terhadap isi dan lingkungan kebijakan. Asumsi dasar yang di bangun, kebijakan bisa saja mengalami kegagalan di lapangan jika isi dan lingkungan kebijakan tidak menopangnya. Begitupun sebaliknya, kebijakan dapat dikatakan sukses jika isi dan lingkungan kebijakannya mendukung.

Pandangan implementasi yang di populerkan oleh Grindle telah lama menjadi pendekatan untuk mengukur efektifitas dari sebuah kebijakan. ${ }^{7}$ Pendekatan ini terutama banyak digunakan untuk mengevalusi sebuah kebijakan yang outputnya berupa progam atau kegiatan. Pendekatan ini di gunakan untuk melihat, apakah program yang sedang berlangsung efektif, untuk kemudian bisa di teruskan atau sebaliknya. Untuk sampai pada kesimpulan efektif dan tidak efektif inilah menggunakan kriteria yang telah di bangun oleh Grindle yaitu isi dan lingkungan kebijakan. Untuk konteks, penelitian ini pendekatan implementasi Grindle kembali di gunakan. Sebab penelitian ini akan mengukur efektifitas kebijakan, berupa perda Kota Palu No. 3 Tahun 2018 tentang penanganan gelandangan dan pengemis anak

\footnotetext{
${ }^{6}$ Merilee S. Grindle, Good Enough Governance: Poverty Reduction and Reform in Developing Countries, Governance, 17.4 (2004). https://doi.org/10.1111/j.0952-1895.2004.00256.

${ }^{7}$ Thomas and Grindle, Developing Countries, World Development, 18.8 (1990). https://doi.org/10.1016/0305-750X(90)90096-G.
} 
dan perempuan yang berlangsung di kota Palu. Meskipun pada aspek ini, muatan kebijakan tidak secara spesifik mengatur bahwa kegiatan pada perda No. 3 Tahun 2018 mengacu pada kegiatan atau program. Namun, pendekatan Grindle masih relevan untuk melihat khususnya pada aspek pertama yaitu isi kebijakan dengan muatan kepentingan kelompok sasaran dan pelaksana program serta sumber daya yang digunakan. Sementara itu, untuk aspek lingkungan kebijakan aspek yang relevan pada penelitian ini khususnya kepentingan dan strategi aktor yang terlibat. Untuk model implementasi kebijakan Grindle yang digunakan pada penelitian ini dapat dilihat pada alur berikut ini:

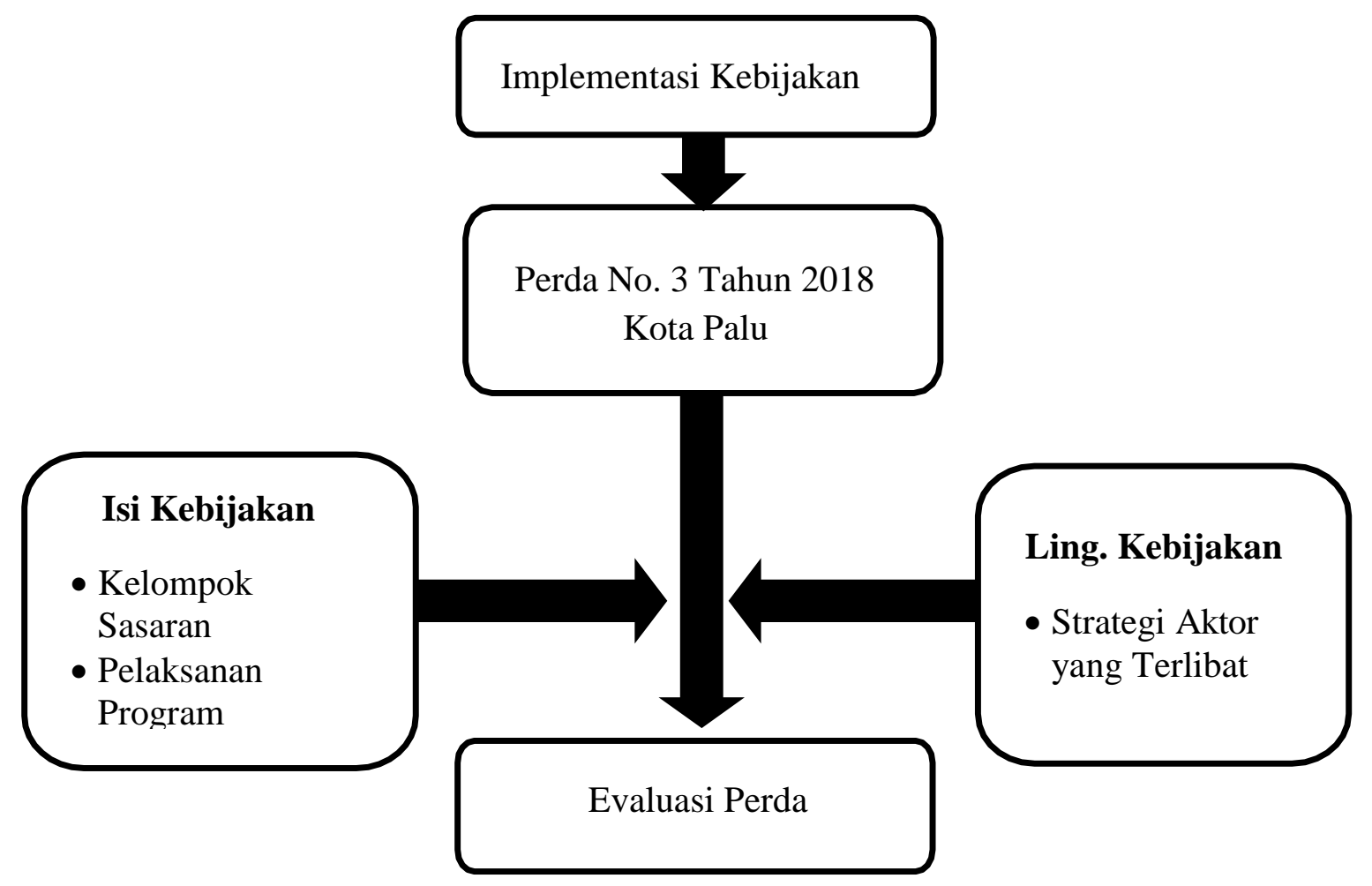

Sumber: Diadopsi dan dimodifikasi dari Model Grindle 


\section{Perda Kota Palu No. 3 Tahun 2018 tentang Gelandangan/Pengemis Anak dan Perempuan di Kota Palu}

Gelandangan seringkali disbandingkan dengan pengemis ataupun pengamen, pada konteks Indonesia mereka lebih dikenal dengansingkatan 'gepeng'. Penertiban gelandangan termaktub dalam dalam UUD 1945 Pasal 34 ayat 1 yang berbunyi: "Fakir miskin dan anak-anak terlantar dipelihara oleh negara". Sementara itu pasal 34 ayat 2 menegaskan; "negara mengembangkan sistem jaminan sosial bagi seluruh rakyat dan memberdayakan masyarakat yang lemah dan tidak mampu sesuai dengan martabat kemanusiaan". Selanjutnya penertiban gelandangan termaktub dalam Pasal 34 ayat 1 dan 2 UUD 1945, UU Nomor 11 Tahun 2009 tentang Ketentuan-Ketentuan Pokok Kesejahteraan Sosial, Peraturan Pemerintah Republik Indonesia Nomor 31 Tahun 1980 tentang Penanggulangan Gelandangan, Anak jalanan, dan Pengemis, dll. Pada bagian pertimbangan di tiap Peraturan yang tertera di atas sama dengan menyatakan:

a) Bahwa gelandangan tidak sesuai dengan norma kehidupan bangsa Indonesia berdasarkan Pancasila dan Undang-Undang Dasar 1945, karena itu perlu diadakan usaha-usaha penanggulangan.

b) Bahwa usaha penanggulangan tersebut, di samping usaha-usaha pencegahan timbulnya gelandangan bertujuan pula untuk memberikan rehabilitasi kepada gelandangan agar mampu mencapai taraf hidup kehidupan, dan penghidupan yang layak sebagai Warga Negara Republik Indonesia.

Pada Peraturan Daerah Kota Palu No. 3 Tahun 2018 juga menggunakan definisi yang hampir sama yang termaktub pada pasal 1 ayat 6 dan 7. Yang secara konklutif dapat diambil intisari maknanya seperti berikut:

"orang yang hidup dalam keadaan tidak sesuai dengan norma kehidupan yang layak dalam masyarakat setempat serta tidak mempunyai tempat tinggal dan pekerjaan tetap di wilayah tertentu dan hidup mengembara di tempat umum." 


\section{Gelandangan/Pengemis Anak dan Perempuan di Kota Palu}

Terkait masalah penanganan gelandangan dan pengemis khususnya Anak dan Perempuan, Pemerintah Kota Palu juga telah memberikan keterangan yang dilansir dari portal SultengRaya.com pada Kamis 27 Mei 2021, yaitu Kepala Dinas Sosial Kota Palu, bapak Romi Sandi Agung, menguraikan, jika Pemerintah Kota Palu sudah memiliki Peraturan Daerah (PERDA) Nomor 3 Tahun 2018, tentang Penanganan Gelandangan dan Pengemis, terdiri dari delapan bab dan 26 pasal, serta ada beberapa ketentuan pidana terkait aktivitas pengemis dan gepeng. Beliau mengatakan bahwa di dalam perda tersebut terdapat upaya-upaya penanganan preventif dan represif. Memberikan kewenangan kepada sejumlah OPD, termasuk kepada Satpol PP melakukan penindakan dan Dinas Sosial diberi kewenangan penjangkauan pembinaan dalam hal rehabilitasi sosial. Ia juga menambahkan bahwa atas penjangkauannya tersebut, mereka telah menangani sekitar 22 orang pengemis dan gelandangan yang di dominasi oleh anak dan perempuan yang oleh pemerintah Kota Palu telah ditangani di rumah singgah.

Dari hasil pendataan mereka tersebut diperoleh, sebagian mereka tidak berasal dari Kota Palu, melainkan dari sejumlah daerah di luar Kota Palu diantaranya berasal sejumlah kabupaten di Sulawesi Selatan dan Sulawesi Barat. Kepala Dinas Sosial Kota Palu mengatakan bahwa sejauh ini mereka telah mendata dan mengembalikan para pengemis dan gelandangan tersebut ke daerah asal masing-masing, seperti ke Gowa, Mamuju, dan Majene. Sementara yang berasal dari sekitar Kota Palu, telah dikembalikan ke orang tuanya masing-masing dan didata oleh Dinas Sosial.

\section{Implementasi Kebijakan Perda: Isi Kebijakan}

Bagian ini akan melihat implementasi kebijakan Perda No. 3 Tahun 2018 kota Palu tentang Gelandangan/Pengemis Anak dan Perempuan dengan menggunakan pendekatan implementasi Grindle khususnya untuk melihat dari isi kebijakan. Secara subsbtansi, perda No 3 Tahun 2018 telah memuat unsur-unsur yang sangat prinsip 
terkait dengan penanganan gelandangan/pengemis anak dan perempuan di kota Palu. Diantaranya telah memuat unsur-unsur tentang karakteristik umum gelandangan dan pengemis. Bagian karakteristik umum gelandnagan dan pengemis memberikan definisi yang lengkap tentang apa yang di maksud dengan gelandangan dan pengemis. Sehingga dilihat dari isi kebijakan, Perda ini cukup memadai memberikan batasan penjelasan yang sekaligus meminimasir multitafsir yang dapat memicu terjadinya kesalahpahaman terhadap definisi dari gelandangan dan pengemis. Keuntuhan penjelasan tentang gelandangan dan pengemis sebagaimana yang telah tertuang pada Perda No. 3 Tahun 2018 kota Palu dapat dilihat pada kriteria gelandnagan dan pengemis, bahwa yang di maksud dengan gelandangan dan pengemis harus memuat unsur-unsur sebagai berikut :

a. Tidak memiliki Kartu Tanda Penduduk (KTP) atau identitas penduduk lainnya;

b. Tidak memiliki tempat tinggal yang pasti/tetap;

c. Tidak memiliki penghasilan yang tetap; dan

d. Tidak memiliki rencana hari depan anak-anaknya maupun dirinya.

Sementara itu, batasan definisi tentang pengemis juga secara lengkap telah di jelaskan pada Perda No. 3 Tahun 2018, yang secara eksplesit tertuang pada pasal 4. Pada pasal tersebut dikatakan bahwa seseorang dapat dikatakan sebagai pengemis ketika memenuhi kriteria-kriteria sebagai berikut:

a. Meminta-minta di rumah penduduk, pertokoan, persimpangan jalan (lampu lalu lintas), pasar, tempat ibadah, tempat keramaian dan tempat umum lainnya;

b. Bekerja sendirian atau berkelompok (baik keluarga atau masyarakat);

c. Mata pencahariannya tergantung pada belas kasihan orang lain;

d. Berpakaian kumuh dan compang camping; dan

e. Memperalat sesama untuk memperoleh belas kasihan orang lain.

Selain aspek definisi yang telah dimuat oleh Perda No. 3 Tahun 2018, aspek penanganang gelandangan dan pengemis juga termaktub dalam perda tersebut. 
Dikatakan bahwa penanganan gelandangan dan pengemis yang ada di Kota Palu menggunakan lima skema.

Pertama skema preventif, skema ini lebih banyak bertumpu pada upaya penanganan gelandangan dan pengemis dengan mendorong kegiatan-kegiatan yang lebih produtif. Diantaranya upaya preventif yang tertuang pada Perda No. 3 Tahun 2018 yaitu peningkatan keterampilan melalui kegiatan pelatihan dan pendampingan. Kedua skema represif, model pendekatan ini di atur pada Perda No 3 Tahun 2018 pada pasal 7. Skema represif adalah upaya penanganan gelandangan dan pengemis di kota Palu dengan melakukan tindakan fisik. Tindakan fisik dalam tafsiran penulis adalah upaya meminimasir gelandangan dan pengemis yang di lakukan oleh instansi terakit di kota Palu, seperti diantaranya penertiban gelandangan dan pengemis. Skema ketiga melalui rehabilitasi sosial, merupakan upaya penanaganan gelandangan dan pengemis yang dilakukan dengan oleh pemerintah kota Palu melalui seperangkat kegiatan yang bertujuan untuk memulihkan kondisi sosial gelandangan dan pengemis. Pendekatan untuk rehabilitasi sosial lebih bersifat umum dan tidak berfokus pada individu tetapi lebih luas pada lingkungan sosial. Pendekatan ini telah diatur pada Perda No 3 Tahun 2018 di pasal 8, pasal 9 dan pasal 10. Skema ke empat dilakukan melalui reintegrasi sosial, yaitu skema penanganan gelandangan dan pengemis dengan melibatkan stakeholder yang lebih luas, antara instansi dan instansi terkait di lingkup pemerintah kota Palu. Skema reintegrasi sosial juga melibatkan keluarga sebagai aktor utama dalam upaya penanaganan gelandangan dan pengemis di kota Palu. Terakhir, skema pembinaan dan pengawasan. Bagian pembinaan dan pengawasan sebagai alur terakhir dari upaya penanganan gelandangan dan pengemis yang berlangsung di kota Palu sebagaimana yang telah di muat dalam Perda No. 3 Tahun 2018.

Secara sederahana, ilustrasi dari rangkaian penanganan gelandangan dan pengemis di kota Palu dapat di lihat dalam skema berikut ini: 
145 | MUSA WA, Vol. 13 No.1 Juni 2021 : 134-149
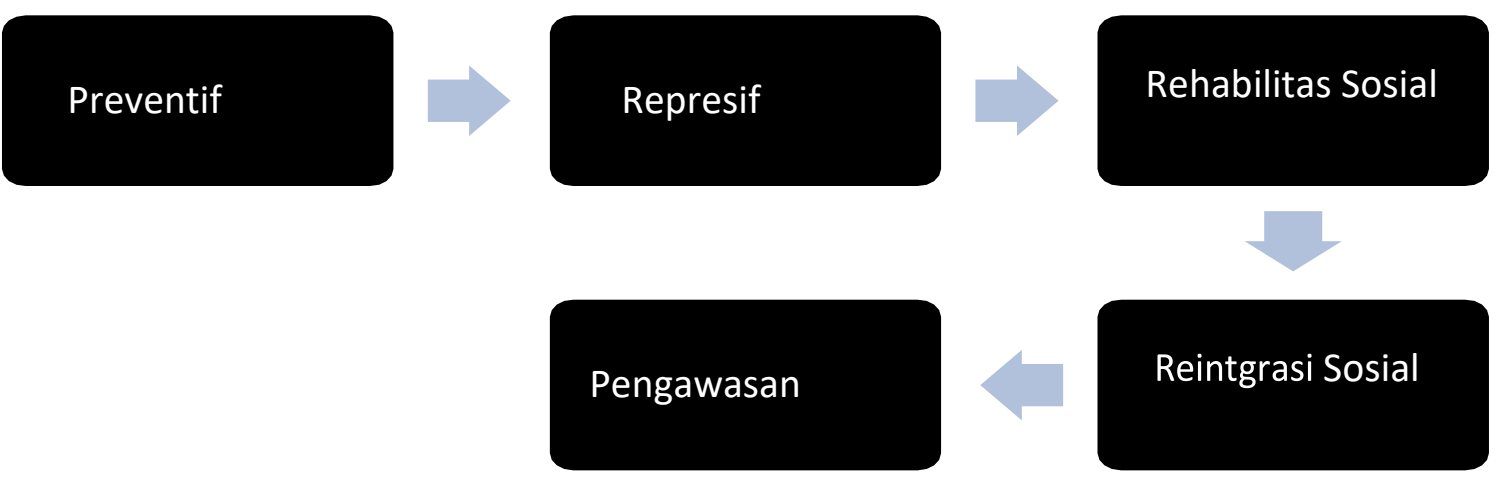

Selain aspek yang telah disebutkan diatas, pada Perda No.3 Tahun 2018 di tinjau dari isi kebijakan juga memuat keterlibatan stakeholder lain selain pemerintah, yaitu melibatkan masyarakat secara luas. Dalam hal ini, penulis melihat dari aspek isi perda, perda ini telah mendorong ruang partisipasi masyarakat. Masyarakat secara langsung ikut dilibatkan dalam mencegah munculnya gelandangan dan pengemis yang aa di kota Palu. Keterlibatan masyarakat yang tidak hanya secara perseorangan tetapi juga pada organisasi-organsiasi kemasyarakarakatan. Meskipun demikian, secara substansi bagian dari perda ini secara keseluruhan masih terlalu abstrak dalam hal pembiayaan. Bagian pembiayaan yang di atur oleh perda dijelaskan tidak sebaik pada bagian penejlasan karakteristik umum. Sehingga pada bagian ini penulis melihat dapat menimbulkan tafsir yang beragam dari pelaksana program di lapangan. Apalagi, pada perda penggunaan dan kewenangan pembiayaan tidak di sebutkan secara tegas.

Secara keseluruhan, jika melihat isi kebijakan sebagaimana kecamata analisis implementasi yang di populerkan oleh Grindle, maka isi kebijakan yang tertuang pada Perda No. 3 Tahun 2018 secara substansi Perda ini cukup memadai sebagai alas hukum untuk memberikan batasan dan penjelasan tentang gelandangan dan pengemis yang ada di kota Palu. Sehingga dalam hal isi, penulis melihat perda ini telah memuat unsur- unsur yang sangat kompleks. Tinggal realisasi dan implementasi pelaksanaan, yang akan di jelaskan lebih lanjut pada bagian lingkungan kebijakan. 


\section{Lingkungan Kebijakan: Strategi Aktor yang Terlibat}

Gelandagan dan pengemis di kota Palu menjadi masalah sosial yang multidimensi. Persoalan ini tidak hanya menjadi tanggung jawab pemerintah kota Palu semata, tetapi menjadi tanggung jawab sosial banyak stakeholder termasuk sektor swasta dan civil society. Keterlibatan sektor-sektor lain dalam hal penanganan gelandangan dan pengemis juga telah diperkuat dalam aturan Perda No. 3 Tahun 2018 di bagian keterlibatan masyarakat. Namun, pada aspek lain banyaknya aktor yang terlibat dalam penanganan gelandangan dan pengemis yang diatur dalam Perda No. 3 Tahun 2018 menimbulkan persoalan lain. Diantaranya, memicu lingkungan kebijakan yang lebih luas. Lingkungan kebijakan yang lebih luas sebagai konsekuensi dari adanya perluasan akibat aktor yang terlibat juga semakin kompleks. Pada konteks tertentu, perluasan area aktor yang berimplikasi pada ikut meluasnya lingkungan kebijakan akan berpotensi menimbulkan tarik ulur aktor. Akan ada dominasi aktor diantara aktor-aktor lain yang terlibat. Tarik ulur aktor terutama ketika adanya titik berangkat dari masing-masing aktor yang tidak sepaham. Biasanya, di lapangan kesalahpahaman antara aktor terjadi akibat strategi terhadap pembacaan penanganan gelandangan dan pengemis yang tidak sepaham.

Perbedaan pemahaman antara aktor yang terlibat pada konteks tertentu akan mendorong konflik antar aktor. Konflik antar aktor kemudian bisa berdampak domino pada realisasi implementasi kebijakan perda yang terkendal. Hal ini bisa berimbas pada gagalnya implementasi kebijakan perda. Sebaliknya, jika keselarasan terbangun antara sesama aktor yang terlibat, maka realisasi implementasi kebijakan perda akan semakin mudah.

Pada konteks kebijakan Perda No. 3 Tahun 2018 tentang penanganan gelandangan dan pengemis dilihat dari kecamata implementasi kebijakan Grindle sejauh pengamatan penulis lingkungan kebijakan khususnya untuk strategi aktor yang terlibat belum cukup signifikan memberikan dampak terhadap realisasi implementasi kebijakan Perda No. 3 Tahun 2018. Penulis melihat, aspek ini tidak memberikan 
atensi berarti pada perda sebab dilihat dari aktor yang terlibat data observasi lapangan menunjukan untuk penanganan gelandangan dan pengemis di kota Palu aktor yang terlibat belum terlalu kompleks. Aktor yang terlibat masih didominasi oleh pemerintah kota Palu, sementara untuk swasta dan civil society sejauh ini belum menunjukan keterlibatan yang signifikan. Hal ini secara tidak langsung memberikan dampak positif sebab, intensitas konflik antar aktor yang terlibat pada kebijakan perda tidak terlalu besar bahkan nyaris tidak ada.

Efek lanjutannya, strategi aktor yang digunakan dalam mewujudkan upaya penanganan gelandangan dan pengemis juga tidak terlalu besar. Sebab, tidak ada aktor yang lian yang terlibat selain pemerintah kota Palu. Hal ini yang ikut membenarkan bahwa dalam realisasi implementasi kebijakan Perda No. 3 Tahun 2018 belum berjalan dengan baik. Masih banyak di temui di beberapa titik gelandangan dan pengemis yang ada di kota Palu. Khususnya di titik-titik yang sangat strategis seperti pada depan kantor DPRD kota Palu.

Minimnya aktor yang terlibat pada upaya penanganan gelandangan dan pengemis berimplikasi domino pada lingkungan kebijakan. Sebagaimana pandangan yang dikembangkan oleh Grindle bahwa lingkungan kebijakan sangat menentukan realisasi implementasi kebijakan. Semakin banyak aktor yang terlibat, lingkungan kebijakan juga semakin luas yang implikasi pada strategi aktor yang juga harus semakin kompleks. Sebaliknya, jika aktor yang terlibat tidak terlalu kompleks maka lingkungan kebijakan juga akan semakin sempit yang efek dominonya pada strategi aktor dalam mewujudkan implementasi Perda No. 3 Tahun 2018 yang juga tidak semakin kompleks.

Untuk konteks Perda No. 3 Tahun 2018 strategi aktor tidak terlalu menonjol. Hal ini disebabkan oleh lingkungan kebijakan yang tidak terlalu luas, sebagai implikasi dari keterlibatan aktor yang minimnya. Secara keseluruhan, dapat dilihat bahwa realisasi dari implementasi kebijakan Perda No. 3 Tahun 2018 tentang penanganan gelandangan dan pengemis di kota Palu belum berlangsung secara efektif. 


\section{PENUTUP}

Kemiskinan telah memicu munculnya gelandangan dan pengemis terutama di daerah-daerah perkotaan seperti yang berlangsung di Kota Palu. Gelandangan dan pengemis menjadi masalah sosial yang semakin memperihatinkan, sebab telah melibatkan anak usia dini dan perempuan. Dua kelompok yang sangat rentan. Berbagai upaya telah dilakukan oleh pemerintah di semua tingkatan, termasuk oleh pemerintah kota Palu diantaranya menyelesaikan masalah gelandangan dan kemiskinan dengan intervensi normatif; melalui perda. Salah satu perda yang telah di terbitkan oleh pemerintah kota Palu dalam upaya menangani gelandangan dan pengemis anak dan perempuan adalah Perda No. 3 Tahun 2018.

Secara normatif Perda No. 3 Tahun 2018 bertujuan untuk memberikan perlindungan sosial dan kesejahteraan kepada masyarakat kota Palu, khususnya untuk masyarakat di kelompok rentan yaitu gelandangan dan pengemis. Hanya saja, sejauh ini realisasi dari implementasi kebijakan Perda No. 3 Tahun 2018 belum terlihat secara optimal. Dengan menggunakan analisis implementasi Grindle, artikel ini menyimpulkan bahwa pada aspek isi kebijakan, Perda No. 3 Tahun 2018 secara substansi sudah mengatur muatan kebijakan dengan snagat baik. Perda No. 3 Tahun 2018 telah memuat unsur-unsur yang sangat subtantif, seperti pada pembasatan definisi yang di jelaskan dengan sangat jelas dan rinci.

Hanya saja, dari aspek lingkungan kebijakan terumata pada aspek strategi aktor belum berlangsung secara optimal. Hal ini karena aktor yang terlibat pada upata penangana gelandangan dan pengemis di kota Palu masih minim. Aktor yang terlibat lebih banyak di dominasi oleh pemerintah kota Palu, sementara itu untuk swasta dan civil society belum menunjukan keterlibatan yang signifikan. 
149 | MUSA WA, Vol. 13 No.1 Juni 2021 : 134-149

\section{DAFTAR PUSTAKA}

Abdul Syaban, Arsidik Asuru, La Iru, Implementasi Kebijakan Pemerintah Daerah Di Bidang Pendidikan Non Formal Pada Anak Jalanan Di Kota Kendari, Journal Of Chemical Information And Modeling, 53.9 (2013).

Arifani, Moh Anif. Sari, Avid Leonardo. and Rifkah Rifkah, Aplikasi Regulasi Pembinaan Anak Jalanan Oleh Dinas Sosial Dan Penanggulangan Kemiskinan Kota Bandung, Jurnal Ilmu Sosial dan Ilmu Politik, Vol. 8, No. 2 (2018).

Febriandini, Ade Putri. and others, Studi Implementasi Program Kesehatan Ibu Dan Anak Di Puskesmas Tlogosari Kulon Kota Semarang, Journal Of Public Policy And Management Review, Vol. 5, No. 2 (2016).

Imron, Masyuri. Kemiskinan Dalam Masyarakat Nelayan, Jurnal Masyarakat dan Budaya, Vol. 5, No. 1 (2003).

Merilee S. Grindle, Good Enough Governance: Poverty Reduction and Reform in Developing Countries, Governance, Vol. 17, No. 4 (2004). https://doi.org/10.1111/j.0952-1895.2004.00256.

Simanjuntak, Kardin. Implementasi Kebijakan Desentralisasi Pemerintahan di Indonesia, Jurnal Bina Praja, Vol. 07, No. 02 (2015), https://doi.org/10.21787/jbp.07.2015.111-130.

Thomas and Grindle, Developing Countries, World Development, 18.8 (1990). https://doi.org/10.1016/0305-750X(90)90096-G. 